\title{
Effect of non-crop vegetation types on conservation biological control of pests in olive groves.
}

Conservation biological control (CBC) is an environmentally sound potential alternative to the use of chemical insecticides. It involves modifications of the environment to promote natural enemy activity on pests. Despite many CBC studies increasing abundance of natural enemies, there are far fewer demonstrations of reduced pest density and very little work has been conducted in olive crops. In this study we investigated the effects of four forms of non-crop vegetation on the abundance of two important pests: the olive psyllid (Euphyllura olivina) and the olive moth (Prays oleae). Areas of herbaceous vegetation and areas of woody vegetation near olive crops, and smaller patches of woody vegetation within olive groves, decreased pest abundance in the crop. Inter-row ground covers that are known to increase the abundance of some predators and parasitoids had no effect on the pests, possibly as a result of lack of synchrony between pests and natural enemies, lack of specificity or intra-guild predation. This study identifies examples of the right types of diversity for use in conservation biological control in olive production systems. 


\section{Effect of non-crop vegetation types on conservation biological}

2 control of pests in olive groves.

Paredes $\mathrm{D}^{1}$, Cayuela $\mathrm{L}^{2}$, Gurr $\mathrm{GM}^{3}$ and Campos $\mathrm{M}^{1}$.

${ }^{1}$ Grupo de Protección Vegetal, Departamento de Protección Ambiental, Estación

Experimental de Zaidín, CSIC, Profesor Albareda $n^{\circ}$ 1, 18008, Granada, Spain.

2 Área de Biodiversidad y Conservación, Departamento de Biología y Geología, Universidad Rey Juan Carlos I, Tulipán s/n, 28933, Móstoles, Spain.

${ }^{3}$ EH Graham Centre for Agricultural Innovation (Primary Industries, NSW and Charles Sturt University), PO Box 883, Orange, NSW 2800, Australia.

\section{1. Introduction}

5 The use of synthetic pesticides for pest control in conventional agriculture is coming under

6 closer scrutiny due to rising concerns about environmental and health problems (Meehan et

7 al., 2011) including the recent ruling by the European Union to suspend the use of

8 neonicotinoid insecticides (Stokstad, 2013). Biological control has evolved in recent decades

9 as a response to such concerns and one approach, 'conservation biological control' includes

10 practices such as the modification of the environment to boost the impact of natural enemies

11 of pests (Eilenberg, Hajek \& Lomer, 2001). The modification of the environment can involve

12 features on or close to farms (Boller, Häni \& Poehling, 2004), such as hedges, woodland

13 patches, grasslands, wildflower strips, ruderal areas, conservation headlands and even stone

14 heaps. The extent of spill-over of natural enemies between adjacent vegetation types can be

15 large (Bowie et al., 1999). These various forms of modifications increase the diversity of

16 vegetation and habitat structure, which in turn increases the availability of natural enemy

17 resources such as nectar, pollen, alternative prey, and shelter (Altieri \& Letourneau, 1982;

18 Landis, Wratten \& Gurr, 2000).

19 The increase in natural enemy biodiversity that is often reported in studies with 
20 supplementary non-crop vegetation (Bianchi, Booij \& Tscharntke, 2006; Thies \& Tscharntke,

21 1999) can potentially increase ecosystem function in the form of top-down forces from the

22 third to the second trophic level (Landis, Wratten \& Gurr, 2000). Yet, the extent to which

23 top-down forces are effectively activated by non-crop vegetation is variable and often not

24 reported in papers that achieve effects purely at the third trophic level. Some studies have

25 reported a decrease in herbivore density in the presence of ground cover vegetation

26 (Aguilar-Fenollosa et al., 2011; Altieri \& Schmidt, 1986) or patches of natural vegetation in

27 and around farms (Thies \& Tscharntke, 1999; Thomson \& Hoffmann, 2009), whilst others

28 have found no effect (Bone et al., 2009; Danne et al., 2010). Lack of effect can be the result

29 of intraguild predation (Polis, Myers \& Holt, 1989; Straub, Finke \& Snyder, 2008), disruption

30 of biological control by alternative prey presence (Koss \& Snyder, 2005) or asynchrony

31 between herbivores and their natural enemies (Fagan et al., 2002; Perdikis, Fantinou \& Lykouressis, 2011). Additionally, there is the risk that pest species might be attracted by, and make use of non-crop vegetation, thus increasing - rather than decreasing - their abundance (Baggen \& Gurr, 1998; Gurr, van Emden \& Wratten, 1998; Wratten \& van Emder, 1995). The foregoing factors underline the importance of identifying the right kinds of diversity for use in any conservation biological control program. in olive grove conservation biological control (inter-row ground covers, areas of herbaceous vegetation and areas of woody vegetation near olive crops, and smaller patches of woody vegetation within olive groves) on the abundance of olive moth (Prays oleae (Bernard)), and olive psyllid (Euphyllura olivina (Costa)).

There is a strong need for research on olive pests because world economic losses are estimated at $€ 800$ million per year, with an additional cost of $€ 100$ million year in agrochemical products (IOBC, 2005). These figures do not include the potential 
environmental and health costs of insecticide use. Research on the potential for conservation biological control approaches to lessen reliance on insecticide use on olive pests is scarce (Herz et al., 2005). A recent study in this system revealed that ground cover increased the abundance of spiders, Hymenopteran parasitoids and one species of predatory Heteroptera (Deraeocris punctum) (Paredes, Cayuela \& Campos, 2013). If alternative forms of vegetation diversity can reduce pest abundance, the adoption of these by olive growers could alleviate the associated cost of conventional pest control, whilst potentially also improving other ecosystems services such as soil fertility, prevention of soil erosion (Cullen et al., 2008; Hartwig \& Ammon, 2002) and pollination (Tscheulin et al., 2011).

\section{Material and methods.}

\subsection{Study species.}

In this study we focused on the nymphs of E. olivina and the adults of the flower generation of $P$. oleae. The nymphs of E. olivina appear from mid April to the end of May and, during this period, are susceptible to the attack by natural enemies. The flower generation of $P$. oleae is the most abundant of the three generations, and lays the eggs of the fruit generation. There is a strong correlation between the adults of the flower generation and the degree of olive fruit infestation (Ramos et al., 1989), and therefore it is assumed that controlling the population of the flower generation of $P$. oleae might ultimately reduce fruit infestation. Larvae of the flower generation of P. oleae appear at the same time as that of E. olivina nymphs. Other pests such as Saissetia oleae (Olivier) or Bactrocera oleae (Gmelin), that are potentially serious insects for the olive culture, were not included in this study because their attack was very low for the first in the study area. B. oleae used to appear from September to November, a period out of the target in this study. Several potential natural enemies of $E$. olivina and P. oleae were found in the experimental orchard. The most abundant were the spider families Thomisidae, Philodromidae, Araneidae, Salticidae, Linyphiidae and 
70 Oxyopidae; the parasitoids families Scelionidae, Encyrtidae, Elasmidae and Braconidae; the

71 ant genus Tapinoma sp., Camponotus spp. and Plagiolepis sp.; the predatory Heteropteran

72 species Brachynotocoris ferreri n. sp. Baena (in litteris), Pseudoloxops coccineus (Meyer

73 Dur), Deraeocoris punctum (Rambur) and Anthocoris nemoralis (Fabricius); the green

74 lacewing species Chrysoperla carnea (Stephens); and the order Raphidioptera.

75 2.2. Vegetation treatments

76 The study was conducted in an experimental olive grove (235 ha) located in southern Spain, 77 near the city of Granada $\left(37^{\circ} 17^{\prime} \mathrm{N}\right.$ and $\left.3^{\circ} 46^{\prime} \mathrm{W}\right)$. Full information about the study area can be 78 found in Paredes, Cayuela \& Campos, 2013). Four different forms of non-crop vegetation 79 were investigated: inter-row ground covers, areas of herbaceous vegetation and areas of 80 woody vegetation near olive crops, and smaller patches of woody vegetation within olive 81 groves (Figure 1). Effects of the inter-row ground covers treatment were investigated by establishing 12 square-shaped plots each containing a grid of 7x7 olive trees and an area of $4900 \mathrm{~m}^{2}$. Plots were separated by150 m from each other. Half of the plots were treated with glyphosate and oxyflourfen in early spring 2010 and 2011 to remove weeds and provide a bare soil treatment. In the remaining plots, spontaneous herbaceous vegetation was allowed to grow in a 2.5 m wide strip between tree lines (Figure 1a). Climatic conditions were different in both years. Average annual precipitation was higher in 2010 (565.12 mm) than in 2011 (368.82 mm). In 2010 mean average temperature was lower $\left(22.1^{\circ} \mathrm{C}\right)$ than in $2011\left(24.5^{\circ} \mathrm{C}\right)$.

89 Average maximum monthly temperature from April to June was $24.7^{\circ} \mathrm{C}$ in 2010 and $27.8^{\circ} \mathrm{C}$ in 90 2011. Ground cover was composed of herbaceous plants dominated by Medicago minima L., 91 Anacyclus clavatus Desf., Hordeum leporinum L., Lolium rigidum Gaudich., and Bromus madritensis L. The area beside the groundcover strips were treated with the same herbicides used for the bare soil treatment. No insecticides were used in the grove for two years before 94 the beginning of the experiment onwards. Other treatments were naturally occurring 
vegetation patches.

Herbaceous vegetation was adjacent to some of the olive areas and dominated by Anchusa sp., Anacyclus clavatus Desf. and Echium plantagineum L (Figure 1b). Likewise, large woody patches were present beside some areas of olives as relatively extensive areas, partly in ravines, and comprised predominantly of Phyllirea angustifolia L. and Quercus rotundifolia Lam. (Figure 1c). Finally, small woody patches were comprised of shrubby vegetation patches occupying no more than a few square meters and located within the olive area, usually at hilltops, in areas of difficult access to machinery (Figure 1d). This community consisted mainly of Genista hirsuta M. Vahl, Cistus albidus L., Cistus clusii Dunal, and Rosmarinus officinalis L.

Arthropod samples were collected every ten days, weather allowing, from late March to early July in 2010 and from early April to early July in 2011 giving 12 sampling dates in 2010 and nine dates in 2011. Sampling employed a modified vacuum device, CDC Backpack Aspirator G855 (John W. Hock Company, Gainsville, Florida, USA), which was used for two minutes per tree. On each date 16 olive trees (a grid of $4 \times 4$ ) were randomly selected for sampling. Arthropods were stored on ice for transportation to the laboratory, where they were identified and counted.

To incorporate the effect of each type of vegetation in models of $E$. olivina and $P$. oleae abundance (see below), we digitized all patches of non-crop vegetation using aerial photographs, and a 1x1 m resolution grid was superimposed upon the resulting vector maps. A bivariate Gaussian kernel density function (Diggle, 1985) was computed from the 1x1 m grid and a value was calculated for each plot in order to obtain a distance-weighted measure of the influence of each vegetation type on that plot. As we hypothesize that pest densities are going to be mediated by trophic interactions with their potential natural enemies, a standard deviation of 120 m was chosen for the Gaussian kernel density function, as Miliczky \& Horton (2005) reported this as the maximum distance of dispersal of some groups of natural enemies in orchards. This measure also allowed incorporating the influence of vegetation at distances further than $120 \mathrm{~m}$ by assigning progressively lower weights, by means of the 
123 Gaussian density function, as we moved away from the plot. These analyses were performed

124 with the R package 'spatstat' (Baddeley \& Turner, 2005).

125 2.4. Data modelling

126 A Gaussian function was used to describe the predicted abundance of the pests in response to

151 study due to we allow the parameter d to vary between years (for further details see Paredes, PeerJ reviewing PDF | (v2013:05:495:1:1:NEW 4 Jul 2013) 
152 Cayuela \& Campos, 2013). The most complex model, taking into account the effects of

153

154

155

156

157

158

159

160

161

162

163

164

165

ground cover, natural vegetation, the interaction between these two, and inter-annual variability, can be expressed as:

Abundance $=\left(a_{i j}+\gamma_{i j}\right) \cdot \exp \left(-\left(\left(X-b_{i}\right)^{2} / 2 \cdot c_{i}^{2}\right)\right)$

where $\gamma_{i j}$ represents the effect of natural vegetation patches on the maximum abundance of pests in each treatment (j) and year (i), which results from multiplying parameters $d . h e r b_{i j}$, d.lwp $p_{i j}$ and $d . s w p_{i j}$, estimated separately for bare soil and ground cover each year, by the observed values of herbaceous (Xherb), large (Xlwp) and small woody patches (Xswp) density, respectively, according to the following expression:

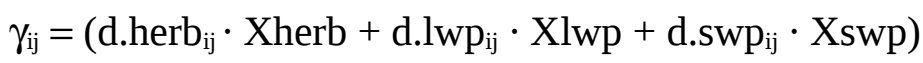

We used simulated annealing, a global optimization procedure, to determine the most likely parameters (i.e. the parameters that maximize the log-likelihood) given our observed data (Goffe, Ferrier \& Rogers, 1994). We used a Poisson error structure for all response variables. Alternative models were compared using the Akaike Information Criterion $\left(\mathrm{AIC}_{\mathrm{c}}\right)$ corrected for small sample size (Burnham \& Anderson, 2002). Models with a difference in $\mathrm{AIC}_{\mathrm{c}}>2$ indicate that the worst model has virtually no support and can be omitted from further consideration. We used asymptotic two-unit support intervals to assess the strength of evidence for individual maximum likelihood parameter estimates (Edwards, 1992). The $R^{2}$ of the model fit (1 - SSE/SST, sum of squares error (SSE) sum of squares total (SST)) of observed versus predicted was used as a measure of goodness-of-fit. All analyses were performed using the 'likelihood' package (Murphy, 2012) written for the R environment (R Development Core Team, 2012). R codes can be found in Appendix 1.

Based on best model predictions, we calculated the proportional change in pest abundance under the influence of a single vegetation type ( $\left.\mathrm{PCA}_{\mathrm{VT}}\right)$ as follows:

PeerJ reviewing PDF | (v2013:05:495:1:1:NEW 4 Jul 2013) 
$\mathrm{PCA}_{\mathrm{VT}}=\Delta \mathrm{A}_{\mathrm{VT}} /$ Maximum abundance

where $\Delta \mathrm{A}_{\mathrm{VT}}$ is the difference between the predicted abundance in the presence of ground cover or maximum vegetation density for a particular vegetation type and the predicted abundance in the absence of any ecological infrastructure. PCA $\mathrm{VT}_{\mathrm{VT}}$ ranks from 1 to -1 , reflecting the proportional increase (positive values) or decrease (negative values) of pest abundance under the influence of a particular vegetation type.

\section{Results}

A total of 7,530 insects were trapped during the study. Of these 4,940 were adults of P. oleae and 2,590 were nymphs of E. olivina. For both of these major pests, the best model included the effect of vegetation and inter-annual variability in the parameters $a, b, c$ and $d$ (E. olivina: $\mathrm{R}^{2}=0.60$; . oleae: $\mathrm{R}^{2}=0.95$; Table 1). Ground cover did not have any effect on the abundance of pest species and consequently we did not calculate the proportional change in abundance for ground cover versus bare soil. Both species displayed differences in abundance between years. Euphyllura olivina displayed a two-fold lower abundance in 2010 (45 individuals/plot) than in 2011 (94 individuals/plot) (Table 2). For P. oleae the opposite temporal trend was apparent with 213 individuals/plot in 2010 but only 90 individuals/plot the following year (Table 2).

The effect of vegetation varied among pests and years (Table 2). Proportional change in abundance $\left(\mathrm{PCA}_{\mathrm{VT}}\right)$ allowed quantifying the relative effect of each vegetation type on pest abundance, whether positive or negative (Figure 2). Herbaceous vegetation had a negative effect on the abundance of both pests in both years (Figure 2). For P. oleae this effect was associated to a reduction in abundance of ca. $20 \%$ in 2010 , but the reduction was much smaller in 2011 (Figure 2). For E. olivina there was a reduction in abundance of ca. 20\% in both years (Figure 2). Small and large woody vegetation was associated to opposing 
responses for the two pests. For E. olivina, the influence of small woody vegetation was associated to a reduction the population by 16\% and 59\% in 2010 and 2011, respectively (Figure 2). For P. oleae there was a negligible effect in 2010 and an estimated increase of ca. 12\% in 2011 (Figure 2). Large woody vegetation was associated to a reduction of P. oleae by 19\% and 11\% in 2010 and 2011, respectively, but had no effect in 2010 and a positive effect in 2011 with E. olivina increasing in abundance by 13\% (Figure 2).

\section{Discussion}

Non-crop vegetation can have the effect of suppressing pest populations by increasing the abundance of different groups of natural enemies (Thies \& Tscharntke, 1999; Landis, Wratten \& Gurr, 2000; Boller, Häni \& Poehling, 2004; Bianchi, Booij \& Tscharntke, 2006) provided that the right types of vegetation are identified and promoted for use. In this study herbaceous and woody vegetation within or adjacent to olive groves offered scope to reduce pest abundance through an indirect effect rule by the presence of natural enemies. Specifically, herbaceous vegetation was associated with a consistent reduction of the abundance of both pests though this effect was slight for P. oleae in 2011 when this pest was relatively rare. Small woody areas within the olive crop were associated with a reduction of E. olivina in both years but especially in 2011 when this pest was relatively common, giving a reduction of nearly $60 \%$. For P. oleae, small woody areas gave a significant reduction in 2010 when this pest was relatively common but a modest increase in the following year when its density was relatively low. In contrast, the influence of large woody vegetation patches led to decreased pest abundance except for E. olivina in 2011 when this pest was relatively common. The consistent effect found in this study (large woody vegetation on the abundance P. oleae and small woody vegetation on the abundance of E. olivina) could be due to large uncultivated areas being better source of natural enemies than small areas (Tscharntke et al., 2008) but, small areas distributed within the crop may facilitate natural enemies to move quickly into the 
crop (Bianchi, Booij \& Tscharntke, 2006). As P. oleae appears later than E. olivina this could explain why small woody vegetation affects more consistently to E. olivina and large woody vegetation to $P$. oleae.

Reductions in pest numbers are likely to be associated with enhanced densities of predatory Heteroptera in olive plots as a response to herbaceous and small woody vegetation (Paredes, Cayuela \& Campos, 2013) as these pests, especially E. olivina, are highly specific for olive and changes to their numbers would have nothing to do with emigration. Members of this taxon, such as Anthocoris nemoralis or Deraeocoris punctum, have been described as predators of both E. olivina and P. oleae (Kidd et al., 1999; Morris et al., 1999b; Scutareanu et al., 1999; Agustí, Unruh \& Welter, 2003). The variability observed between years in the proportional change of abundance of the two pest species might suggest an important role of climatic conditions in modulating pest responses to their environment. Changes in temperature and humidity could alter the phenology of pests and natural enemies and, therefore, influence insect population growth rate (Wolda, 1988; Logan, Wolesensky \& Joern, 2006), which might ultimately change the effectiveness of natural enemies in controlling pest abundance from one year to the next.

There was no effect of inter-row ground covers and this is consistent with the results reported by Albedis et al. (2004) and Rodriguez, González \& Campos (2009). Notably, inter-row ground covers were found to increase the abundance of different groups of natural enemies including spiders, parasitoids and ants in an earlier study of this system (Paredes, Cayuela \& Campos, 2013) but the present results indicate a lack of top down effects on P. oleae and $E$. olivina. This could reflect a lack of synchrony between these herbivore species and the natural enemies that exhibited a response to ground cover vegetation. Studies in other systems have indicated the significance of synchrony for pest suppression (Fagan et al., 2002; Perdikis, Fantinou \& Lykoeressis, 2011). This means an increase in the abundance of natural 
enemies promoted by ground cover occurs at a time of the year when pest abundance is low. This could be the case for spiders, which were enhanced by the ground covers (Paredes, Cayuela \& Campos, 2013) but reach their maximum abundance by mid August. This contrasts with the nymphs of E. olivina and the eggs and larvae of P. oleae that reach their maximum densities much earlier, in April or May. Thus spiders are responding to prey availability rather than suppressing population increase. Alternatively, the species of natural enemies favoured by ground cover might not be those that utilise E. olivina and P. oleae as prey. Parasitoids clearly fall within this category, since most of those reported to be enhanced by ground cover (Paredes, Cayuela \& Campos, 2013) are not specific for the study pest species. Parasitoids of E. olivina and P. oleae mainly belong to families Encyrtidae and Elamisdae, which represent together less than $30 \%$ of the abundance of those reported from this study system. In fact, $50 \%$ of the parasitoids belonged to the hymenopteran family Scelionidae, which mostly attack the eggs of spiders (Fitton, Shaw \& Austin, 1987) and chrysopids in olive groves (Campos, 1986). This inter-guild predation would weaken top-down forces in olive groves. Related to this effect, the increase in abundance of ants reported by Paredes, Cayuela \& Campos (2013) might have a detrimental effect on other natural enemies in olive groves (Morris et al., 1999a; Pereira et al., 2004). In summary, even though ground cover enhanced the populations of some groups of natural enemies, this did not lead to reduce pest abundance so is not an optimal form of vegetation for use in olive conservation biological control.

This study has indicated the relative suitability of various types of non-crop vegetation in conservation biological control of E. olivina and P. oleae and provides an example of how such studies can help growers achieve the sometimes difficult task of balancing the practicalities of conserving appropriate forms of vegetation in ways that cause little or no disruption to normal agronomic practices (Gurr et al. 2005). Prays oleae is currently the 
principal insect pest in olive groves in the Mediterranean Europe so it needs to be the primary target of management. Against this pest, herbaceous vegetation and large woody vegetation adjacent to olive crops provided the most consistent level of suppression. Small woody vegetation within olive groves appears less suitable as it gave modest reductions or increases in P. oleae densities. In areas where E. olivina is more likely to be the primary pest, small woody vegetation within olive groves offers more value, especially since its presence led to major reductions in the study year during which it was more common. Inter-row ground covers are shown to be unsuitable because, though these promote various natural enemy taxa, they do not provide suppression of either of the major pests. A longer-term study would be important to validate these tentative recommendations and identify precisely the underlying ecological process that can influence the success of olive pest conservation biological control.

\section{Acknowledgements}

We thank to Belen Cotes, Mario Porcel, Rafael Alcalá, Herminia Barroso and Luisa Fernández for their field and laboratory assistance; Juan Castro for his management of the experimental olive grove.

\section{References}

Aguilar-Fenollosa E, Pascual-Ruiz S, Hurtado MA, Jacas JA. 2011. Efficacy and economics of ground cover management as a conservation biological control strategy against Tetranychus urticae in clementine mandarin orchards. Crop Protection 30:1328-1333.

Aldebis HK, Avila A, Mata M, Vargas-Osuna E. 2004. Evaluación de los daños causados por la polilla del olivo, Prays oleae Bern. En distintas variedades y condiciones de cultivo. Boletín Sanidad Vegetal Plagas 30:649-656.

Altieri MA, Letourneau DK. 1982. Vegetation management and biological control in agroecosystems. Crop Protection 1:405-430. 
Altieri MA, Schmidt LL. 1986. The dynamics of colonizing arthropod communities at the interface of abandoned, organic and commercial apple orchards and adjacent woodland habitats. Agriculture Ecosystems \& Environment 16:29-43.

Agustí N, Unruh TR, Welter SC. 2003. Detecting Cacopsylla pyricola (Hemiptera: Psyllidae)in predator guts using COI mithocondrial markers. Bulletin of Entomological Research 93:179-185.

Baddeley A, Turner R. 2005. spatstat: An R package for analyzing spatial point patterns. Journal of Statistical Software 12:1-42.

Baggen LR, Gurr GM. 1998. The influence of food on Copidosoma koehleri (Hymenoptera : Encyrtidae), and the use of flowering plants as a habitat management tool to enhance biological control of potato moth, Phthorimaea operculella (Lepidoptera : Gelechiidae). Biological Control 11:9-17.

Bianchi F, Booij CJH, Tscharntke T. 2006. Sustainable pest regulation in agricultural landscapes: a review on landscape composition, biodiversity and natural pest control. Proceedings of the Royal Society B-Biological Sciences 273:1715-1727.

Boller EF, Häni F, Poehling HM. 2004. Ecological infrastructures: ideabook on functional biodiversity at the farm level. Lindau: IOBC.

Bone NJ, Thomson LJ, Ridland PM, Cole P, Hoffmann AA. 2009. Cover crops in Victorian apple orchards: Effects on production, natural enemies and pests across a season. Crop Protection 28:675-683.

Bowie MH, Gurr GM, Hossain Z, Baggen LR, Frampton CM. 1999. Effects of distance from field edge on aphidophagous insects in a wheat crop and observations on trap design and placement. International Journal of Pest Management 45:69-73.

Burnham KP, Anderson DR. 2002. Model selection and multimodel inference: a practical information-theoretic approach. New York: Springer-Verlag. 
Campos M. 1986. Influence of parasitism on Chrysoperla carnea populations in olive orchards of Southern Spain. Neuroptera Internacional 4:97-105.

Canham CD, Uriarte M. 2006. Analysis of neighborhood dynamics of forest ecosystems using likelihood methods and modeling. Ecological Applications 16:62-73.

Cullen R, Warner KD, Jonsson M, Wratten SD. 2008. Economics and adoption of conservation biological control. Biological Control 45:272-280.

Danne A, Thomson LJ, Sharley DJ, Penfold CM, Hoffmann AA. 2010. Effects of Native Grass Cover Crops on Beneficial and Pest Invertebrates in Australian Vineyards. Environmental Entomology 39:970-978.

Diggle P. 1985. A Kernel-method for smoothing point process data. Applied Statistics-Journal of Royal Statistics Society 34:138-147.

Edwards AWF. 1992. Likelihood-expanded edition. Baltimore: Johns Hopkins University Press.

Eilenberg J, Hajek A, Lomer C. 2001. Suggestions for unifying the terminology in biological control. BioControl 46:387-400.

Fagan WF, Lewis MA, Neubert MG, van den Driessche P. 2002. Invasion theory and biological control. Ecology Letters 5:148-157.

Fitton MG, Shaw MR, Austin AD. 1987. The Hymenoptera associated with spiders in Europe. Zoological Journal of the Linnean Society 90:65-93.

Goffe WL, Ferrier GD, Rogers J. 1994. Global optimization of statistical functions with simulated annealing. Journal of Econometrics 60:65-99.

Gurr GM, van Emden HF, Wratten SD. 1998. Habitat manipulation and natural enemy efficiency. In: Barbosa P, ed. Conservation biological control. San Diego: Academic Press, 155-183.

Gurr GM, Wratten SD, Tylianakis J, Kean J, Keller M. 2005. Providing plant foods for 
natural enemies in farming systems: balancing practicalities and theory. In: Wäckers FL, van Rijn PCJ, Bruin J, eds. Plant-provided food for carnivourous insects: a protective mutualism and its applications. New York: Cambridge University Press, 326-347.

Hartwig NL, Ammon HU. 2002. 50th Anniversary - Invited article - Cover crops and living mulches. Weed Science 50:688-699.

Herz A, Hassan SA, Hegazi E, Nasr FN, Youssef AA, Khafagi WE, Agamy E, Ksantini M, Jardak T, Mazomenos BE, Konstantopoulou MA, Torres L, Gonçalves F, Bento A, Pereira JA. 2005. Towards sustainable control of Lepidopterous pests in olive cultivation. Gesunde Pflanzen 57.

IOBC, 2005. Integrated protection of olive crops. Chania: IOBC

Jarraya A. 2004. Principaux nuisibles des plantes Cultivées et des denrées stockées en Afrique du Nord. Leur biologie, leurs ennemis naturels, leurs dégâts, leur contrôle. Tunis: Edition Climat Publication.

Johnson JB, Omland KS. 2004. Model selection in ecology and evolution. Trends in Ecology and Evolution 19:101-108.

Kidd NAC, Campos M, Symondson WOC, Morris T. 1999. Heterópteros depredadores presentes en el olivar y su incidencia sobre Prays oleae (Lepidoptera: Plutellidae). Fruticultura profesional 107.

Koss AM, Snyder WE. 2005. Alternative prey disrupt biocontrol by a guild of generalist predators. Biological Control 32:243-251.

Landis DA, Wratten SD, Gurr GM. 2000. Habitat management to conserve natural enemies of arthropod pests in agriculture. Annual Review of Entomology 45:175-201.

Logan JD, Wolesensky W, Joern A. 2006. Temperature-dependent phenology and predation in arthropods systems. Ecological Modelling 196:471-482. 
Malumphy C. 2011. Olive psyllid Euphyllura olivina (Hemiptera: Psyllidae), a Mediterranean pest of olive breeding outdoors in Britain. British Journal of Entomology and Natural History 24:17-21.

Meehan TD, Werling BP, Landis DA, Gratton C. 2011. Agricultural landscape simplification and insecticide use in the Midwestern United States. Proceeding of the National Academy of Science USA 108:11500-11505.

Morris TI, Campos M, Kidd NAC, Jervis MA, Symondson WOC. 1999a. Dynamics of the predatory arthropod community in Spanish olive groves. Agricultural and Forest Entomology 1:219-228.

Morris TI, Campos M, Kidd NAC, Symondson WOC. 1999b. What is consuming Prays oleae (Bernard) (Lep.: Yponomeutidae) and when: a serological solution? Crop Protection 18:17-22.

Miliczky ER, Horton DR. 2005. Densities of beneficial arthropods within pear and apple orchards affected by distance from adjacent native habitat and association of natural enemies with extra-orchard host plants. Biological Control 33:249-259.

Murphy L. 2012. Likelihood: Methods for maximum likelihood estimation. R Package version 1.5 .

Paredes D, Cayuela L, Campos M. 2013. Synergistic effects of ground cover and adjacent natural vegetation on the main natural enemy groups of olive insect pests. Agriculture, Ecosystems \& Environment 173: 72-80.

Pelekassis CD. 1962. A contribution to the study of nomenclature, taxonomy, biology, ecology and the natural parasitisation of the olive kernel borer Prays oleae (Bernard). Annual Benaki Phytopathology Institute 4:181-308.

Perdikis D, Fantinou A, Lykouressis D. 2011. Enhancing pest control in annual crops by conservation of predatory Heteroptera. Biological Control 59:13-21. 
Pereira JA, Bento A, Cabanas JE, Torres LM, Herz A, Hassan SA. 2004. Ants as predators of the egg parasitoid Trichogramma cacoeciae (Hymenoptera : Trichogrammatidae) applied for biological control of the olive moth, Prays oleae (Lepidoptera : Plutellidae) in Portugal. Biocontrol Science and Technology 14:653-664.

Polis GA, Myers CA, Holt RD. 1989. The ecology and evolution of intraguild predation: Potential competitors that eat each other. Annual Review of Ecology and Systematics 20:297-33.

R Development Core Team. 2012. R: a language and environment for statistical computing. Vienna: R Foundation for Statistical Computing. Available at http://www.R-project.org.

Ramos P, Campos M, Ramos JM. 1998. Long-term study on the evaluation of yield and economic losses caused by Prays oleae Bern in the olive crop of Granada (Southern Spain). Crop Protection 17:645-647.

Ramos P, Campos M, Ramos JM, Jones OT. 1989. 9 years of studies on the relationship between captures of male olive moths, Prays oleae Bern (Lepidoptera, Hyponomeutidae) in sex-pheromone baited traps and fruit infestation by the subsequent larval generation (1979-1987). Tropical Pest Management 35:201-204.

Rodriguez E, Gonzalez B, Campos M. 2009. Effects of cereal cover crops on the main insect pests in Spanish olive orchards. Journal of Pest Science 82:179-185.

Scutareanu P, Lingeman R, Drukker B, Sabelis MW. 1999. Cross-correlation analysis of fluctuations in local populations of pear psyllids and anthocorid bugs. Ecological Entomology 24:354-362.

Stokstad E. 2013. Pesticides under fire for risks to pollinators. Science 340: 674-676.

Straub CS, Finke DL, Snyder WE. 2008. Are the conservation of natural enemy biodiversity and biological control compatible goals? Biological Control 45:225-237. 
432 Thies C, Tscharntke T. 1999. Landscape structure and biological control in agroecosystems.

433

434

435

436

437

438

439

440

441

442

443

444

445

446

447 Science 285:893-895.

Thomson LJ, Hoffmann AA. 2009. Vegetation increases the abundance of natural enemies in vineyards. Biological Control 49:259-269.

Tscharntke T, Bommarco R, Clough Y, Crist TO, Kleijn D, Rand TA, Tylianakis JM, van Nouhuys S, Vidal S. 2008. Conservation biological control and enemy diversity on a landscape scale (Reprinted from Biological Control, vol 43, pg 294-309, 2007). Biological Control 45: 238-253.

Tscheulin T, Neokosmidis L, Petanidou T, Settele J. 2011. Influence of landscape context on the abundance and diversity of bees in Mediterranean olive groves. Bulletin of Entomological Research 101:557-564.

Wratten SD, van Emder HF. 1995. Habitat management for enhanced activity of natural enemies of insect pests. In: Glen DM, Geaves MP, Anderson HM, Eds. Ecology and integrated farming systems. Chinchester: John Wiley, 117-145.

Wolda H. 1988. Insect seasonality: Why? Annual Review of Ecology and Systematics 19:1-18. 


\section{Table $\mathbf{1}_{\text {(on next page) }}$}

Comparison of alternative models (using $\mathrm{AIC}_{\mathrm{c}}$ ) for the pests tested in the study.

The best model (lowest $\mathrm{AIC}_{\mathrm{C}}$ ) is indicated in boldface type. The number of parameters and $\mathrm{R}^{2}$ refer to the best model. For brevity, we have presented in Table 1 only the most parsimonious (i.e. lowest AIC $_{c}$ ) of all possible models that include inter-annual variability with one, two or three parameters varying between years. 


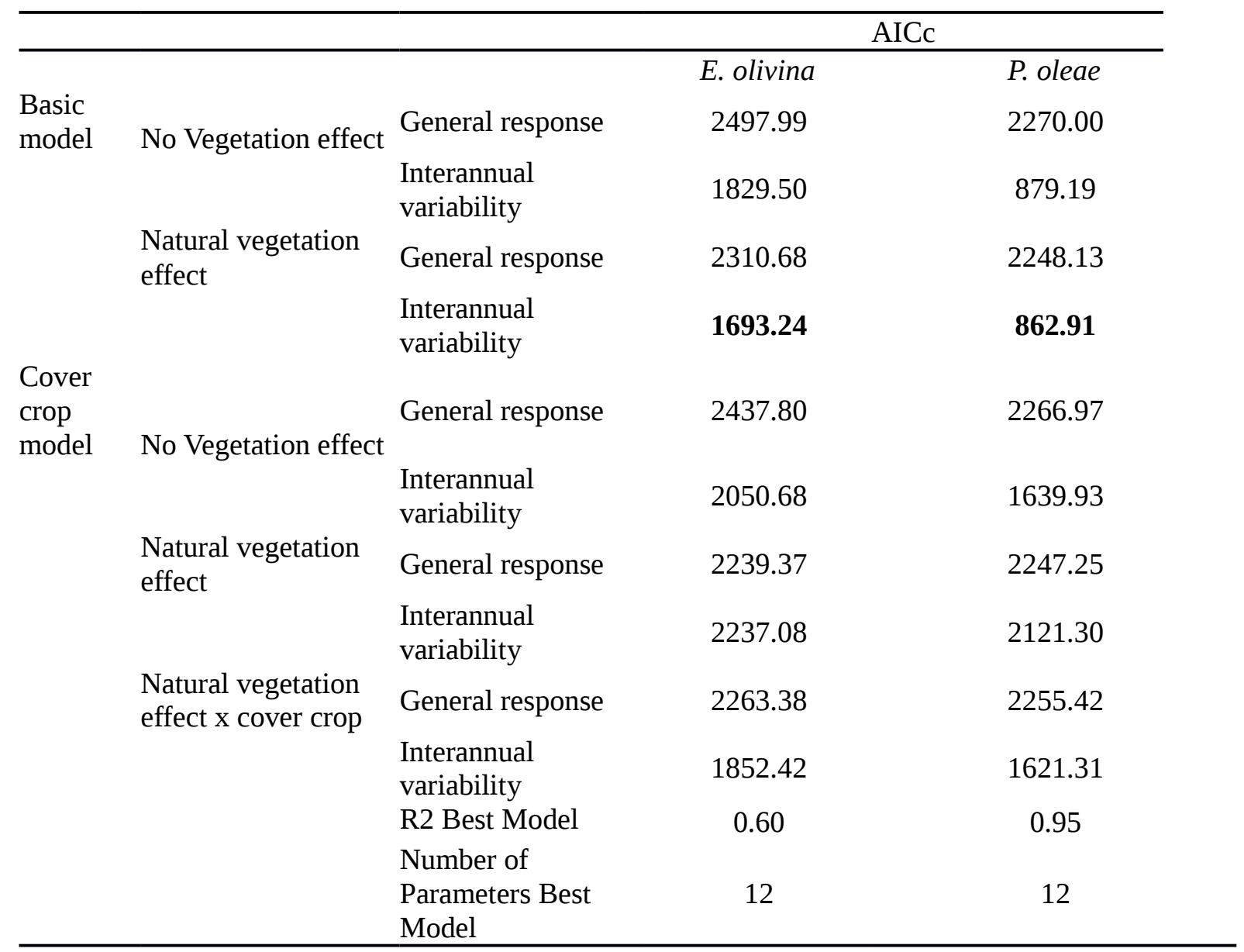




\section{Table $2_{\text {(on next page) }}$}

Table 2. Parameter estimates and two-unit support intervals (in brackets) for the most parsimonious models of abundance of the pests tested in this study.

Parameter $a$ is the maximum abundance of the pest in each year (2010, 2011); $b$ and c represent the mean and standard deviation of the Gaussian curve in different years. The parameters d.herb, d.lwp and d.swp represent the effect of herbaceous, large and small woody natural vegetation on the maximum abundance of the pests in each year. 


\begin{tabular}{|c|c|c|c|}
\hline & & E. olivina & P. oleae \\
\hline \multicolumn{4}{|c|}{$\mathrm{a}$} \\
\hline & 2010 & 45 & 213 \\
\hline & & {$[48 ; 53]$} & {$[209 ; 220]$} \\
\hline & 2011 & 99 & 90 \\
\hline & & {$[96 ; 102]$} & {$[86 ; 95]$} \\
\hline \multicolumn{4}{|c|}{ b } \\
\hline & 2010 & 129 & 169 \\
\hline & 2011 & 120 & 162 \\
\hline \multicolumn{4}{|c|}{ C } \\
\hline & 2010 & 0.102 & 0.152 \\
\hline & & {$[0.098 ; 0.104]$} & {$[0.151 ; 0.154]$} \\
\hline & 2011 & 0.090 & 0.178 \\
\hline & & {$[0.087 ; 0.093]$} & {$[0.172 ; 0.184]$} \\
\hline \multicolumn{4}{|c|}{ d.herb } \\
\hline & 2010 & -1474.32 & -6097.19 \\
\hline & & [-1956.04; -871.91] & [-7429.27; -4388.74] \\
\hline & 2011 & -2276.73 & -707.05 \\
\hline & & [-2972.59; -1574.81] & [-1869.73; -602.28] \\
\hline \multicolumn{4}{|c|}{ d.lwp } \\
\hline & 2010 & -1034.20 & -14650.07 \\
\hline & & [-2683.31; -909.83] & {$[-18665.02 ;-9521.84]$} \\
\hline & 2011 & 5164.31 & -3797.50 \\
\hline & & [2588.72; 7543.65] & [-6992.69; 348.83] \\
\hline \multicolumn{4}{|c|}{ d.swp } \\
\hline & 2010 & -11190.67 & -5691.26 \\
\hline & & [-5847.34; 15541.83] & [-18370.29; 7631.83] \\
\hline & 2011 & -86071.63 & 18960.74 \\
\hline & & [-79770.35; 92788.34] & [8730.12; 29823.10] \\
\hline
\end{tabular}




\section{Figure 1}

\section{Vegetation treatments}

a) inter row-strips with cover plants (ground cover) and bare soil; b) herbaceous vegetation adjacent to olive groves; c) large woody vegetation adjacent to olive groves; d) small woody patches within olive groves at the top of a hill.
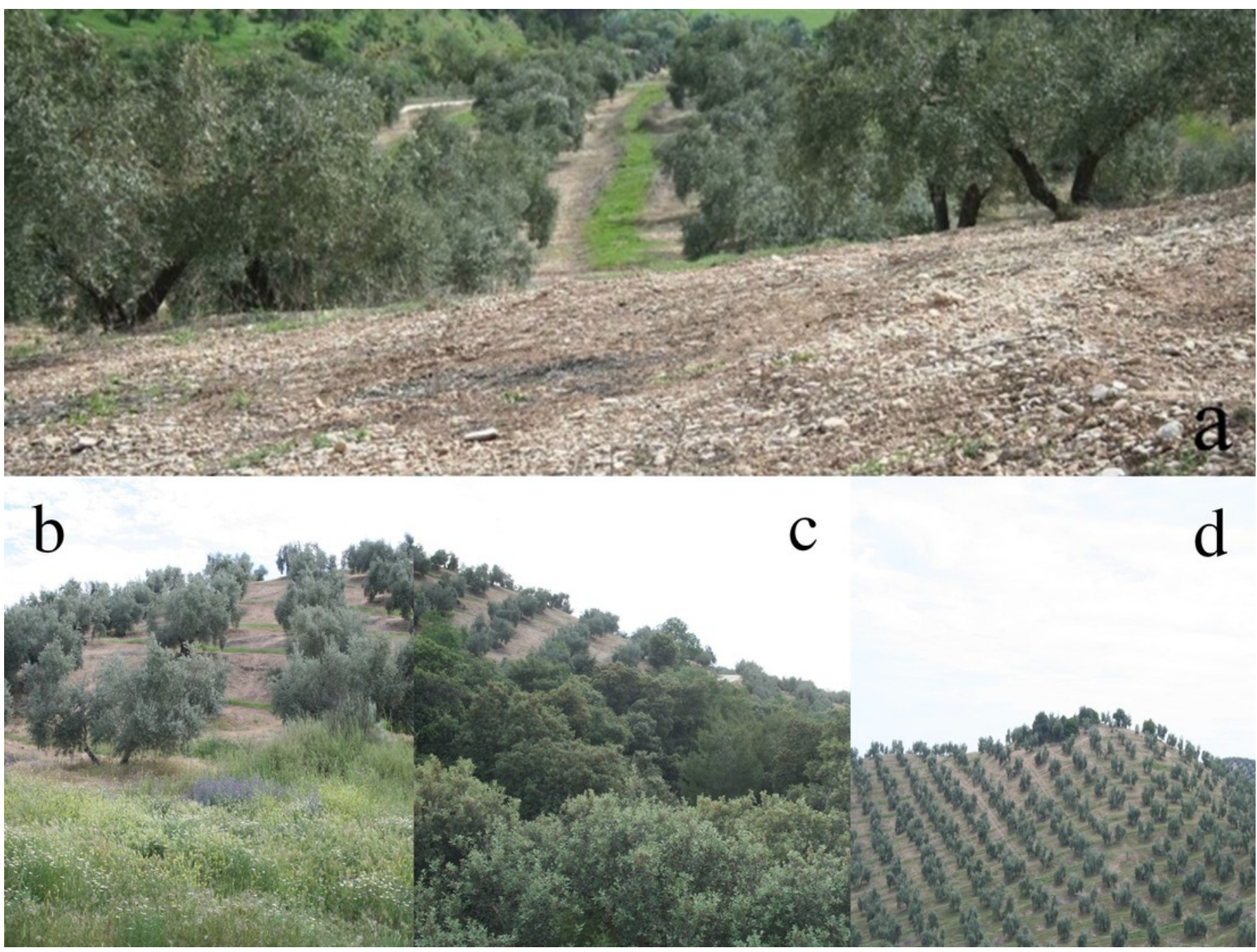


\section{Figure 2}

Proportional change of abundance of the pests under the influence of different types of non-crop vegetation for both years of the study. 

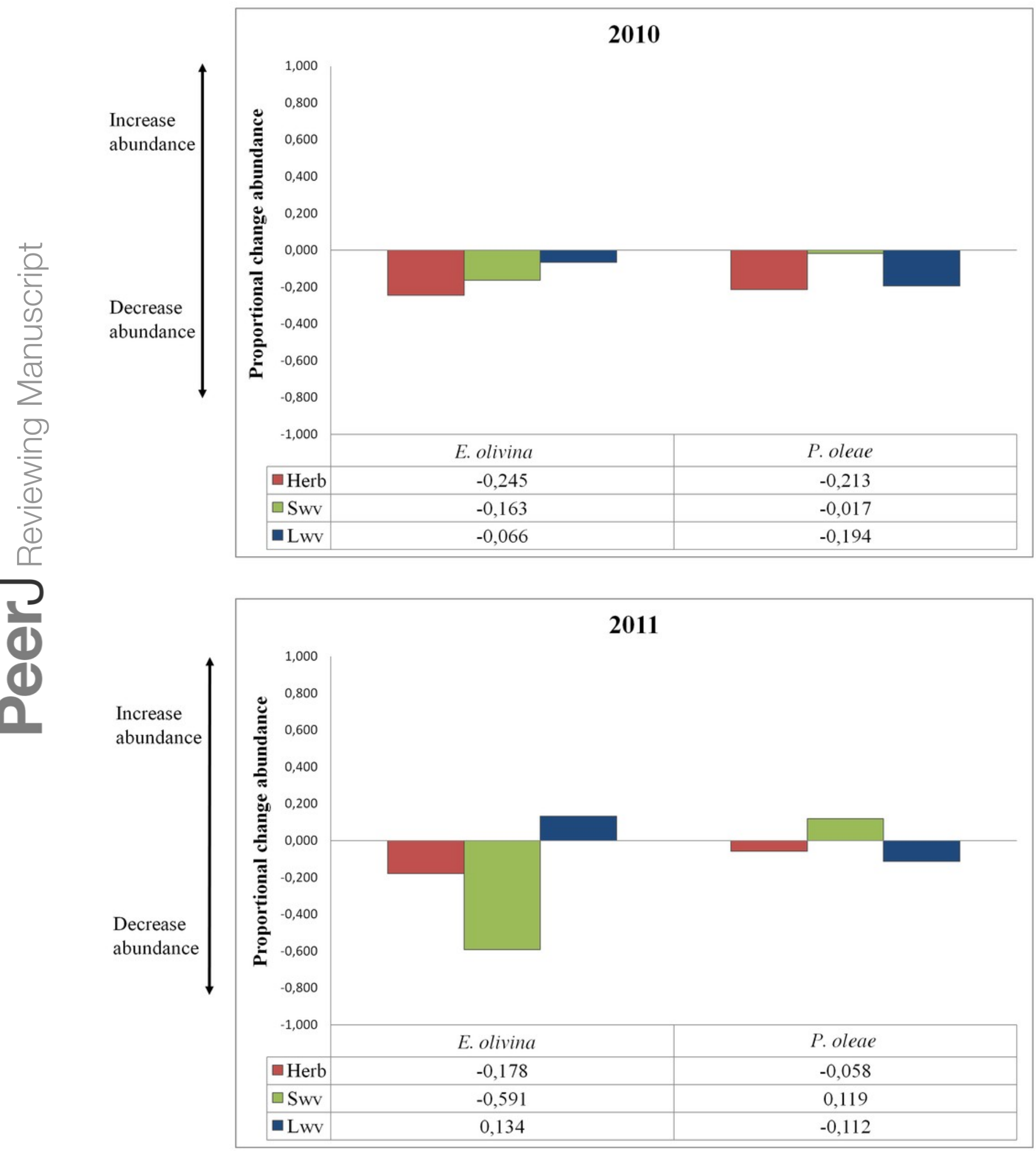